\title{
The Influence of Television Access and Impersonating Violent Contents to Bullying Behavior on Elementary School Children
}

\author{
Nunky Ajeng Arifinda* \\ Department of Family and Consumer Sciences, \\ Faculty of Human Ecology, \\ Bogor Agricultural University \\ Dwi Hastuti \\ Department of Family and Consumer Sciences, \\ Faculty of Human Ecology, \\ Bogor Agricultural University \\ *Corresponding author: nunky.arifinda20@gmail.com
}

\begin{abstract}
Television programs containing violence is now free to be accessed by school age children, particularly children in elementary school. The violent content has negative impact on children, such as bullying behavior to their friends as well as their parents. This research aimed to analyze the influence of television access on bullying behavior among school age children at Bogor villages. This research involved 60 children with age ranges between 10-13 years old in grade 4 and 5. A proportional random sampling in Pamijahan Sub-District, Bogor District was undertaken in this research. Result showed that the intensity of watching television, preferences in watching television, preferences to access violent contents, and impersonation of violent contents significantly correlated to bullying behavior. Multiple linier regression analysis showed that television access and impersonating violent contents had significantly positive effects on bullying behavior on children.
\end{abstract}

Keywords: bullying behavior, elementary school children, impersonating violent contents, rural area, television access

\begin{abstract}
Tayangan televisi yang banyak mengandung kekerasan dapat secara bebas diakses oleh anak usia sekolah. Akibatnya, anak dapat berulang-ulang terpapar muatan kekerasan tersebut dan berpotensi meniru adegan kekerasan tersebut dan melakukan perilaku bullying terhadap teman-teman bahkan orangtuanya. Penelitian ini bertujuan untuk menganalisis pengaruh akses media televisi terhadap perilaku bullying anak usia sekolah di Perdesaan Bogor. Penelitian ini melibatkan 60 anak usia sekolah berusia 10-13 tahun yang duduk di kelas 4 dan 5 SD yang dipilih secara proportional random sampling. Penelitian ini berlokasi di Kecamatan Pamijahan, Kabupaten Bogor. Hasil analisis menunjukkan bahwa lama menonton televisi, preferensi menonton televisi, preferensi mengakses muatan kekerasan, dan peniruan muatan kekerasan berhubungan positif signifikan dengan perilaku bullying. Uji regresi linier berganda menunjukkan bahwa akses media televisi dan peniruan muatan kekerasan berpengaruh positif signifikan terhadap perilaku bullying anak usia sekolah.
\end{abstract}

Kata kunci: akses media televisi, peniruan muatan kekerasan, perdesaan, perilaku bullying, siswa sekolah dasar 


\section{Introduction}

Television is part of the electronic audiovisual media that is accessed freely not only by adults but also by children, especially school age children. The study of Pradekso (2014) which used quasi-experimental methods in District of Tembalang, Semarang, Central Java, has shown that 64 percent of 28 fifth grade students spend 3-6 hours to watch television.

The television program is not always good for children. Television programs for children have mostly scenes of violence. Data from Indonesian Broadcasting Commission (KPI) has shown that during 2009, as many as 835 programs are being complained because of violent contain (Surokim, 2011).

Bullying cases that occur on children are certainly very disturbing. Bullying behavior can be learned by children from various sources, primarily from television. Kuntsche et al. (2006) states that there is a relationship between duration in watching television with bullying behavior, especially verbal bullying. This is confirmed by the study of Stavrinides et al. (2013) involving 417 students on 6th grade in Cyprus in which the preference on violent television program causes the emergence of bullying behavior in children. Therefore, the background of this study concerns on the influence of television access on bullying behavior of the children.

Wang, Iannoti, and Nansel (2009) classify bullying into four types, namely, physical bullying, verbal bullying, indirect bullying (relational bullying), and bullying via the Internet (cyber bullying). Physical bullying is intimidating bullying done by physical movement such as hitting, pinching, pushing, concealing or destroying other people's stuff, and kicking. Verbal bullying is intimidating verbally and directly such as mocking and making fun of others. Indirect bullying is invisible bullying such as making gossip, alienating friends, and viewing cynical.

Bullying cases have occurred many times in Indonesia. Indonesian Child Protection Commission (KPAI) recorded that during the year of 2014, there were 3339 cases of bullying performed by children (Purbasari, 2014). Bullying behavior can be done by school-age children, especially those who are in the end of childhood, about 1012 year old children. Widayanti (2013) reveals that at the age of 10-12 years, children need peer-groups as a place to actualize themselves. Therefore, children need a model of behavior that can be observed and imitated in order to be accepted by the group. Children can learn to behave through observation of some models, such as family, neighbors, and the mass media (Bandura, 1965). This suggests that violent behavior can be learned through imitation of a model that has been observed previously. The learning process is called observational learning.

Problems related to bullying behavior in Bogor Regency are quite high. The study of Latifah (2012) involving 60 school-age children in rural areas in Cibinong, Bogor Regency has revealed that bullying cases occurring in schools performed by primary school-age children grades 4 and 5 reached about 65 percent. Therefore, this study was conducted to: (1) identify school-age children access to television covering the intensity of watching television, the access to violent contents on television programs, and impersonation of violent content; (2) identify the form of verbal, physical, and indirect bullying performed by school-age children; (3) analyze the relationship between parental characteristics, characteristics of children, and access to television with bullying behavior of school-age children; and (4) analyze the influence of parental characteristics, children characteristics, and television access on bullying 
behavior of school-age children.

\section{Method}

\section{Participants}

The population in this study was a complete family who had school-age children living in Ciasihan Village and Ciasmara Village, Pamijahan Sub-District, Bogor Regency. The sample in this study was students at grade 4 and 5 in selected schools while the respondents were 60 people of mothers and elementary schools students. Sampling in this study was conducted using proportional random technique based on the number of students and their sex.

More than half of the children (55\%) were boys, whereas less than half of the children (45\%) were girls. The age of the children ranged between 10-13 years old with the average of 11.25 . Less than half of the children $(48.33 \%)$ were the middle child in their family. Hurlock (2009) distinguishes age into three categories: early adulthood (18-40 years old), middle age (41-60 years old) and older adults ( $>60$ years old). Paternal age was between 29-80 years old with the average of 44.80 (STDEV \pm 10.159$)$. More than half of parents $(53.33 \%)$ were categorized as middle age. Maternal age ranged from 27-60 years old, with the average of 38.57 (STDEV \pm 8.03 ). More than half of mothers were categorized as early adulthood (56.67\%).

Paternal length of study ranged from 0 to16 years. Nine out of 20 fathers (45\%) enrolled school for 6 years while four out of 10 mothers (40\%) enrolled school up to primary school. Most fathers (33.33\%) worked as entrepreneurs or merchants. More than two-thirds of mothers $(71.67 \%)$ did not work or were housewives. The results showed that more than half of families $(53.33 \%)$ were categorized as poor by Poverty Line of West Java (Data and Analysis Center West Java Development, 2014), which the monthly income was less than Rp288.741. The average of family income per capita was Rp320.705,66 (STDEV \pm 247.337,02). BKKBN (1998) divides families into three categories: small families ( $\leq 4$ people), moderate families (5-7 people), and large families (>7 people). About 55 percent of families were categorized as moderate containing 5-7 family members.

\section{Measures}

The design of this study was cross-sectional study. The research location was Pamijahan Sub-District which was purposively selected as the representation of rural areas in the five largest categories of household rice farmers land in Bogor. Data were obtained through interview technique using questionnaires consisting of: (1) questionnaire of sample characteristics (age, sex, and birth order); (2) questionnaire of sample families characteristics (parental age, length of parental education, family income, parental employment, and family size); (3) questionnaire of intensity in watching television, comprising of duration in watching television and preferences in spending more time to watch television were developed from the questionnaire of Rahmawati (2014) with 11 items, 4-point Likert scale $(1=$ strongly disagree to $4=$ very agree), and the reliability value of 0.774 . This questionnaire measured the child's preference and duration in watching television; (4) questionnaire of access to violent content, consisting of duration in accessing violent content and preference in accessing 
violent content were developed from the questionnaire of Muniandy (2013) with 9 items, 4-point Likert scale ( $1=$ strongly disagree to $4=$ very agree), and the reliability value of 0.706 . This questionnaire measured children' preference and duration in accessing television show that contains the elements of violence; (5) Open questions regarding the type of programs frequently watched. This questionnaire asked about the kinds of television show which was often accessed by children; (6) Open questions regarding the frequency of accessing the violent content. This questionnaire measured the frequency of child in accessing television show that contains the elements of violence; (7) questionnaire of impersonating violent content consisting of 4 items, 4point Likert scale $(1=$ strongly disagree to $4=$ strongly agree $)$ and the reliability value of 0.864 . This questionnaire measured the number of violence scenes which has ever been imitated by children; and (8) questionnaire of bullying behavior was developed from questionnaire of Hastuti, Karina, and Alfiasari (2013) with 20 items, 4-point Likert scale $(1=$ never to $4=$ always $)$ and the reliability value of 0.887 . This questionnaire measured bullying behavior which has ever done by children.

\section{Analysis}

The data obtained was processed through a process of editing, coding, scoring, inputting, cleaning, recoding, and analyzing using Microsoft Excel and SPSS. Data were analyzed by descriptive and inferential analysis. Descriptive statistical analysis was used to analyze the characteristics of children, characteristics of parents, children's television access, impersonation of violent content, and bullying behavior of children. Inferential statistical analysis was used to analyze the influence of children's access to television on bullying behavior.

The division performed interval on the results of the questionnaire of children's access to television, which consisted of the intensity of television access, access to the violent content on television, and impersonation of violent content on television. Multiple linear regression analysis was conducted to analyze the influence of television media access to the bullying behavior of school-age children. The formulation of multiple linear regression is as follows:

$$
\mathrm{Y}=\alpha+\beta 1 \mathrm{X} 1+\beta 2 \mathrm{X} 2+\beta 3 \mathrm{X} 3+\beta 4 \mathrm{X} 4+\beta 5 \mathrm{X} 5+\beta 6 \mathrm{X} 6+\beta 7 \mathrm{X} 7+\varepsilon
$$

$\mathrm{Y}=$ bullying behavior; $\alpha=$ constant; $\beta$ (1-7) = regression coefficient; $\mathrm{X}_{1}=$ child's age; $\mathrm{X}_{2}=$ child birth order; $\mathrm{X}_{3}=$ maternal age; $\mathrm{X}_{4}=$ maternal length of education; $\mathrm{X}_{5}=$ income per capita; $\mathrm{X}_{6}=$ television access; $\mathrm{X}_{7}=$ impersonation of violent content; $\varepsilon=$ error 


\section{Result}

\section{Television Access}

Television access in this study is divided into two dimensions, namely the intensity of watching television and access to violent content on television program. The intensity of watching television consists of duration in watching television and children preference in watching television which is longer than other activities. An access of the violent content on television program consists of duration in accessing to violent content and preference in accessing television programs containing violence.

More than half of the children $(66.67 \%)$ had watched television for 3-4 hours in one day (Figure 1). Meanwhile, the rest spread between two levels; 15 percent had watched for 1-2 hours and 18.33 percent had watched for more than 4 hours.

Watching television preference in this study is defined as the children's preference to watch television more than do other activities, such as learning and playing with friends outside the house. Figure 1 shows that more than half of the children $(66.67 \%)$ prefer to watch television rather than did other activities.

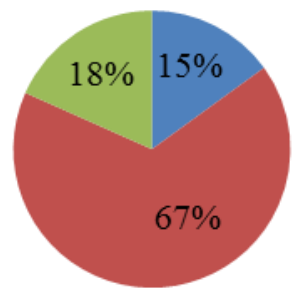

- Almost dislike $(<26.67)$

- Like (26.67-53.34)

$\square$ Very like $(>53.34)$

Figure 1 Distribution of the children based on category of preference in watching television preference

\section{Access to Violent Content}

Access to violent content in this study consists of duration in accessing violent content on television and preferences in accessing violent content. More than half of the children $(68.33 \%)$ access $2-3$ hours to violent content in one day. The study of Signorielli (1990) revealed that it was very dangerous if children accessed television containing violence more frequently. The study of Wilson et al. (2002) revealed that 70 percent of American television shows provided violence with 14 scenes of violence interchangeably within an hour. This indicates that the children have been exposed to quite a lot of scenes of violence when it is accumulated from the duration of accessing television shows (2-3 hours).

Preference to access violent content in this study is defined as the child preference in choosing favorite television program to access violent content. Figure 2 shows that more than two-thirds of the children (85\%) prefer to access television program containing violence. 


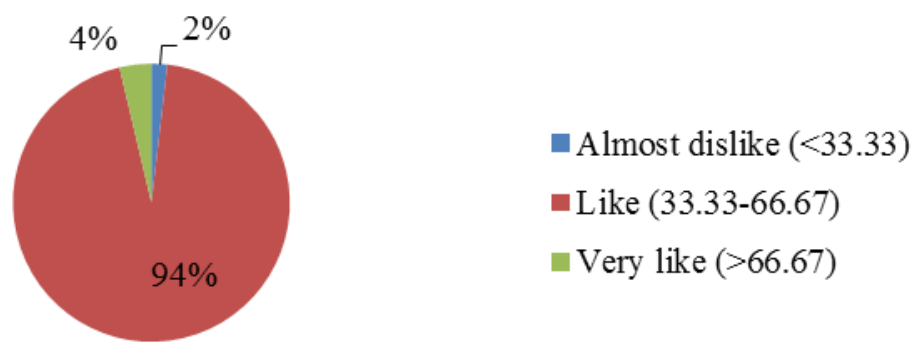

Figure 2 Distribution of the children based on preference category to access violent content

More than two-third of the children (78.33\%) accessed violent content for 2-3 days a week. The smallest portion of the children (10\%) accessed for 4-7 days a week while the rest (10\%) accessed violent content for only 1 day a week.

The program mostly watched by the children in this study is shown in Table 1. Most of the time children watched six programs containing violence and three programs without violence. Besides this six programs, the study of Atmodjo, Zubair, and Budianto (2009) found that the national television broadcast in Indonesia has more than 178 titles of teen soap opera (83 serial television titles, 95 short soap operas/FTV) with a total of 3641 episodes, equivalent to 4019 hours. These teen soap operas which identically contain lots of violence and even sex were watched by school-age children, indicating that there are more children who watch programs containing violence. If the child is allowed to continue accessing television shows with violence, children may imitate and perform the violent behavior to anyone. The study of Laeheem, Kuning, and McNeil (2010) in Thailand proved that children who watched violent cartoons would 2.96 times more likely to do bullying behavior.

Table 1 The title and description of programs frequently watched by the children

\begin{tabular}{|c|c|c|c|c|c|c|}
\hline No. & Description & $\begin{array}{c}\text { Program title } \\
\text { (with } \\
\text { violence) }\end{array}$ & TV Station & Description & $\begin{array}{c}\text { Program title } \\
\text { (without } \\
\text { violence) }\end{array}$ & TV Station \\
\hline 1. & $\begin{array}{l}\text { TV series contain } \\
\text { physical abuse, } \\
\text { like hitting } \\
\text { and kicking }\end{array}$ & $\begin{array}{l}\text { Ganteng- } \\
\text { Ganteng } \\
\text { Serigala }\end{array}$ & SCTV & Quiz & $\begin{array}{c}\text { Olimpiade } \\
\text { Indonesia } \\
\text { Cerdas }\end{array}$ & $\begin{array}{c}\text { Rajawali } \\
\text { TV }\end{array}$ \\
\hline 2. & $\begin{array}{l}\text { TV series contain } \\
\text { physical abuse, } \\
\text { like hitting } \\
\text { and kicking }\end{array}$ & $\begin{array}{l}\text { Tujuh } \\
\text { Manusia } \\
\text { Harimau }\end{array}$ & RCTI & $\begin{array}{l}\text { Religious } \\
\text { lectures }\end{array}$ & $\begin{array}{l}\text { Islam Itu } \\
\text { Indah }\end{array}$ & Trans TV \\
\hline 3. & $\begin{array}{l}\text { Special News } \\
\text { criminal } \\
\text { often aired at } \\
21: 00\end{array}$ & Crime news & $\begin{array}{l}\text { TV One, } \\
\text { ANTV }\end{array}$ & $\begin{array}{l}\text { Talkshow } \\
\text { (set in order } \\
\text { not to } \\
\text { contain } \\
\text { violence) }\end{array}$ & Ini Talkshow & NET \\
\hline 4. & $\begin{array}{l}\text { Cartoon } \\
\text { contain } \\
\text { some } \\
\text { physical abuse, } \\
\text { like hitting } \\
\text { and kicking }\end{array}$ & Boboiboy & $\begin{array}{c}\text { MNC } \\
\text { TV }\end{array}$ & & & \\
\hline 5. & Cartoon & Cemen & MNC & & & \\
\hline
\end{tabular}




\begin{tabular}{|c|c|c|c|c|c|c|}
\hline No. & Description & $\begin{array}{c}\text { Program title } \\
\text { (with } \\
\text { violence) }\end{array}$ & TV Station & Description & $\begin{array}{c}\text { Program title } \\
\text { (without } \\
\text { violence) }\end{array}$ & TV Station \\
\hline & contain & & TV & & & \\
\hline 6. & $\begin{array}{l}\text { some } \\
\text { physical abuse, } \\
\text { like hitting } \\
\text { and kicking } \\
\text { Music program } \\
\text { with many jokes } \\
\text { containing verbal } \\
\text { abuse }\end{array}$ & Dahsyat & RCTI & & & \\
\hline
\end{tabular}

\section{Impersonation of Violent Content}

Impersonation of violent content refers to the imitative behaviors or following the violence displayed on television. The results showed that out of 60 children, more than half $(63.33 \%)$ imitated violent content at moderate level, indicating that half of the violent content is impersonated. On the other hand, there was no child imitated at high level or nearly all of the violent content displayed on television. Yet, there were a small proportion of the children $(36.67 \%)$ who imitated the small amount of the violent content if not at all.

\section{Bullying Behavior}

Table 2 shows that in general children do bullying at low level or not repeatedly. Nearly half of the children $(43.33 \%)$ watched violent cartoons although the bullying behavior shown was relatively low. TV series was another television program which was watched frequently yet the children showed a low level of bullying behavior.

Table 2 Distribution of the children based on the type of programs most viewed and categories of bullying behavior

\begin{tabular}{lcccccc}
\hline \multirow{2}{*}{ Program } & \multicolumn{2}{c}{ Low } & \multicolumn{2}{c}{ Moderate } & \multicolumn{2}{c}{ High } \\
\cline { 2 - 7 } & $\mathrm{n}$ & $\%$ & $\mathrm{n}$ & $\%$ & $\mathrm{n}$ & $\%$ \\
\hline TV series & 23 & 38.33 & 1 & 1.67 & 0 & 0.00 \\
Violent cartoon & 26 & 43.33 & 2 & 3.33 & 0 & 0.00 \\
Crime news & 2 & 3.33 & 0 & 0.00 & 0 & 0.00 \\
Music program & 2 & 3.33 & 0 & 0.00 & 0 & 0.00 \\
Religious program & 1 & 1.67 & 0 & 0.00 & 0 & 0.00 \\
Quiz & 1 & 1.67 & 0 & 0.00 & 0 & 0.00 \\
Talkshow & 2 & 3.33 & 0 & 0.00 & 0 & 0.00 \\
\hline Total & 57 & 95.00 & 3 & 5.00 & 0 & 0.00 \\
Min-Max & & \multicolumn{2}{c}{$0-60$} & & \\
Mean \pm SD & & \multicolumn{2}{c}{$11.67 \pm 11.05$} & \\
\hline
\end{tabular}

As shown in Table 3, nearly all children (93.33\%) do verbal bullying. Children preferred verbal bullying because it was deemed to be normal and could not hurt others physically. Forms of verbal bullying done by the children were supporting and encouraging friends who were hurting another friend, nicknaming rudely, mocking, snapping, and insinuating friend. This is in line with the study of Latifah (2012) which stated that as many as 87 percent of 60 children performed verbal bullying. On the other hand, there was no child in this study who did physical and relational bullying at the same time, such as isolating and looking cynical, then strucking. 
Table 3 Distribution of the children based on type of bullying behavior done

\begin{tabular}{lcc}
\hline Bullying behavior & $\mathrm{n}$ & $\%$ \\
\hline Verbal (nickname rough, snap, and insinuate friend) & 56 & 93.33 \\
Physical (push body and hit friend) & 2 & 3.33 \\
Relational (isolate and look cynical at friend) & 0 & 0.00 \\
Verbal and physical & 1 & 1.67 \\
Verbal and relational & 1 & 1.67 \\
Physical and relational & 0 & 0.00 \\
\hline Total & 60 & 100.00 \\
\hline
\end{tabular}

\section{Factors That Correlate with Bullying Behavior}

Bullying behavior was proved to be correlated with television watching behavior. The longer children accessed television, the higher children' bullying behavior $(\mathrm{r}=0.395 ; \mathrm{p}<0.01)$. The higher the impersonation carried by children towards the violent content on television, the higher children's bullying behavior $(r=0.377$; $\mathrm{p}<0.01)$. The longer children watched television, the higher children's bullying behavior $(\mathrm{r}=0.349 ; \mathrm{p}<0.01)$. Television watching preferences were positively correlated with bullying behavior of children $(\mathrm{r}=0.331 ; \mathrm{p}<0.01)$. This indicates that the more children love to watch television, the higher bullying behavior occupied by children. Preference to access violent content was positively correlated with bullying behavior of children ( $\mathrm{r}$ $=0.266 ; \mathrm{p}<0.01)$. This suggests that the more children like accessing violent content, the higher bullying behavior occupied by children.

\section{Factors That Influence Bullying Behavior}

Table 4 shows that television access significantly positively influences child bullying behavior, indicating that any increase in the score of the television access is likely to increase bullying behavior by 0.211 points. Impersonation of violent content was positively influenced by bullying behavior. This suggests that each increasing score of impersonation of violent content is likely to increase bullying behavior by 0.162 points. This model can explain the effect of bullying behavior by 13.80 percent (adjusted R-square $=0.138 ; \mathrm{p}<0.05$ ), while the rest 86.2 percent is influenced by other variables excluding in this study.

Table 4 Regression analysis of children characteristics, parental characteristics, television access, and the impersonation of violent content on bullying behavior

\begin{tabular}{lccc}
\hline Variable & $\begin{array}{c}\text { Unstandardized } \\
\text { coefficient }(\mathrm{B})\end{array}$ & $\begin{array}{c}\text { Standardized } \\
\text { coefficient }(\beta)\end{array}$ & Sig. \\
\hline Constant & -6.605 & & 0.545 \\
Sex & 1.974 & 0.090 & 0.478 \\
Child birth order & -1.295 & -0.232 & 0.253 \\
Maternal age & 0.146 & 0.106 & 0.599 \\
Maternal length of education & 0.222 & 0.054 & 0.712 \\
Income per capita & $4.536 \mathrm{E}-6$ & 0.102 & 0.442 \\
Access to television & $\mathbf{0 . 2 1 1}$ & 0.257 & $\mathbf{0 . 0 7 2}^{*}$ \\
Impersonation violent content & $\mathbf{0 . 1 6 2}$ & 0.270 & $\mathbf{0 . 0 7 1 *}$ \\
\hline F & & 2.345 & \\
Adjusted R-square & 0.138 & \\
Sig & & $0.037^{* *}$ & \\
\hline Note. $(* *)$ significant at $\mathrm{p}<0.01 ;(*)$ significant at $\mathrm{p}<0.05$ & &
\end{tabular}




\section{Discussion}

The results showed that 66.67 percent of children had watched television for 3-4 hours in a day. Pradekso (2014) suggest that the maximum hour (including low category) for children to watch television is 2 hours in a day. A total of 66.67 percent of the children in this study preferred to watch television than to learn and play with friends outside the house. This implies that duration in watching television done by the children in this study can be considered as quite high. Children are more often linger watching television than do other activities. Some studies suggest that playing outdoors with friends can teach the children to solve their own problems, learn to help his friends, learn to queue, and learn to share (Henderson, Marshall, Fox, and Rubin, 2004; HirshPasek, Golinkoff, Berk, and Singer 2008, as cited in Singer et al., 2009).

A total of 68.33 percent of the children had accessed violent content for 2-3 hours in a day. A similar proportion of the children, 63.33 percent had imitated some violent contents. This indicates that children in this study can access television shows containing violence in a long time. A total of 43.33 percent of the children watched cartoons containing violence, but the bullying behaviors were still relatively low. This is presumably due to the children imitate only some violent contents. Bandura (1965) shows that if the children only imitate some violent contents, it indicates that they have run motivational processes which is responsible for evaluating and choosing whether they will continue or stop the violent behaviors. If the violent behaviors raise penalties from the closest environment of the children, especially the parents, the child will be more likely to not repeat violence or intimidation behaviors, so that bullying behaviors will be relatively low. The high bullying behavior is done repeatedly; if intimidation do not repetitive, the potential for bullying remains low (Wang, 2009).

The results showed that the higher duration of watching television, the higher bullying behavior. The higher preferences of watching television and of accessing violent content from television, as well as the more impersonation of violent content, the higher bullying behavior. After all, this study proved that the television access positively affected bullying behavior. This is in line with the study of Keating (2011) taken place in Ireland toward 161 school-age children which shows that access to the electronic media, such as television and computer games can reduce the aspect of social, cognitive, and emotional of the children so that they tend to do violence. Impersonation of violent content positively affected bullying behavior. Bandura (1965) proves that violence behavior can be learned by the children through observation and imitation of violent content on television.

\section{Conclusion and Recommendation}

\section{Conclusion}

Children in this study prefer watching television than any other activities, such as learning and playing with friends outside the house. They spend 3-4 hours a day in average for watching television. The access of the children to violent content in average was 2-3 hours in a day and 2-3 days in a week. Most of the children often watch violent cartoons, such as "BoBoiBoy" and "Tom and Jerry" and more familiar with the shows containing violence. However, in general the bullying behavior of the children is still relatively low. The duration of watching television of the children has the implication 
on their preferences in watching television and in accessing violent content. Furthermore, they will more likely to impersonate violent content which is correlated with the level of bullying behavior. After all, increasing access to television media and increasing impersonation of violent content will increase bullying behavior of the school-age children.

\section{Recommendation}

Based on the findings of this study, the family especially parent is expected to pay more attention to the intensity of watching television of their children and the programs preference as well. It is purposed to avoid the children from accessing violent content which furthermore to reduce their tendency to imitate violent behavior broadcasted on television. The school is also expected to create a safe and convenient school environment for students, one of which is through optimizing the role of counseling teachers for students to consult or tell their problems in order to prevent bullying behavior. The government is expected to make the selection of television programs in order to prevent any violent television shows.

\section{Reference}

Atmodjo, J. T., Zubair, A., \& Budianto, H. (2009). Potret sinetron remaja di televisi [Portrait of teen soap opera on television]. Jurnal Visi Komunikasi, 2(5), 1-29.

Bandura, A. (1965). Influence of models' reinforcement contingencies on the acquisition of imitative responses. Journal of Personality and Social Psychology, 1(6), 589-595. doi: 10.1037/h0022070.

Hastuti. D., Karina, \& Alfiasari. (2013). Perilaku bullying dan karakter remaja serta kaitannya dengan karakteristik keluarga dan peer group [Bullying and teenage characters and their relationship with the family and peer group characteristics]. Jurnal Ilmu Keuarga dan Konsumen, 6(1), 20-29. Retrieved from http://journal.ipb.ac.id/index.php/jikk/article/view/7700/5963.

Hurlock, E. B. (2009). Psikologi Perkembangan: Suatu Pendekatan Sepanjang Rentang Kehidupan [Developmental Psychology] (Istiwidayanti \& Doedjarwo, Trans.). Jakarta, Indonesia: Erlangga.

Keating, S. (2011). A study on the impact of electronic media, particularly television and computer consoles, upon traditional childhood play and certain aspects of psychosocial development amongst children. International Journal for CrossDisciplinary Subjects in Education, 2(1), 294-303. doi: 10.20533/ijicr.2042.6364.2011.0042.

Kuntsche, E., Pickett, W., Overpeck, M., Craig, W., Boyce, W., \& de Matos, M. G. (2006). Television viewing and form of bullying among adolescents from eight countries. Journal of Adolescent Health, 39(6), 908-915. doi: 10.1016/j.jadohealth.2006.06.007.

Laeheem, K., Kuning, M., \& McNeil, N. (2010, April). Bullying: The identify technique and its major risk factors. International Conference on Humanities and Social Sciences, Singkla University. $\quad$ Retrieved from http://fs.libarts.psu.ac.th/research/conference/proceedings-2/2pdf/002.pdf.

Latifah, F. (2012). Hubungan karakteristik anak usia sekolah dengan kejadian bullying di Sekolah Dasar $X$ di Bogor [Correlation between school age children 
characteristics and bullying incidence in $\mathrm{X}$ Elementary School, Bogor] (Undergraduate thesis). Retrieved from http://www.digilib.ui.ac.id/opac/themes/libri2/detail.jsp?id=20313561\&lokasi=lokal.

Muniandy, R. (2013). Karakteristik kebiasaan menonton televisi di kalangan pelajar Dwiwarna 3 dan SD Negeri No. 106162 [Characteristics of television viewing habits among students Dwiwarna 3 and Elementary School No. 106162]. Retrieved from http://repository.usu.ac.id:123456789/39878.

Pradekso, T. (2014). Pengaruh kampanye pendidikan pada perilaku anak dalam menonton televisi [Effect of an education campaign on child behavior in watching television]. Jurnal Interaksi, 3(1), 1-14. Retrieved from http://ejournal.undip.ac.id/index.php/interaksi/article/view/8197/6717.

Purbasari, I. (2014, August). Fenomena gang anak dalam perkembangan proses sosialisasi di lingkungan belajar [The phenomenon of gangs in the development process of socialization in the learning environment]. Menyiapkan Pendidik yang Melek Hukum Terhadap Perlindungan Anak. Seminar Nasional PGSD FKIP Universitas Muria Kudus.

Singer, D. G., Singer, J. L., D’Agostino, H., \& DeLong, R. (2009). Children's pastimes and play in sixteen nations. American Journal of Play. 283-312. Retrieved from http://www.journalofplay.org/sites/www.journalofplay.org/files/pdf-articles/1-3article-children-pastimes-play-in-sixteen-nations.pdf.

Rahmawati, S. H. (2014). Pengaruh akses media sosial, gaya pengasuhan, dan kekerasan verbal orang tua terhadap karakter siswa SMK di Bogor [The influence of social media access, parenting style, and parental verbal violence on the character of vocational students in Bogor] (Master thesis). Retrieved from http://repository.ipb.ac.id/handle/123456789/71403.

Data and Analysis Center West Java Development. (2014). Tingkat kemiskinan Jawa Barat September 2013 [Poverty Level of West Java in September 2013]. Retrieved from http://pusdalisbang.jabarprov.go.id/pusdalisbang/beritastatistik-45.html.

Signorielli, N. (1990). Television's mean and dangerous world: A continuation of the cultural indicators perspective. In N. Signorielli \& M. Morgan (Eds.), Cultivation analysis: New directions in media effects research (pp. 85-106). Newbury Park, CA: Sage.

Stavrinides, P., Tsivitanou, A., Nikiforou, M., Hawa, V., \& Tsolia, V. (2013). Longitudinal associations between bullying and children's preference for television violence. International Journal of Criminology and Sociology, 2, 72-78.

Surokim. (2011). Pengaturan tentang kekerasan dalam program siaran TV [The regulation of violence in a program broadcast TV]. Jurnal Pamator Ilmu Komunikasi FISIB Universitas Trunojoyo Madura, 5(1).

Wang, J., Iannotti, R. J., \& Nansel, T. R. (2009). School bullying among adolescents in United States: physical, verbal, relational, and cyber. Journal of Adolescent Health, 45(4), 368-375. doi: 10.1016/j.jadohealth.2009.03.021.

Widayanti, W. 2013. Aktualisasi diri anak usia sekolah pada ibu bekerja dan ibu tidak bekerja di SDN Jabungan Banyumanik Semarang [Self-actualization of school age children in working and not working mother and the mother does not work study in Jabungan Banyumanik Elementary School, Semarang]. Jurnal Keperawatan, 1(1), $1-10$. Retrieved from http://jurma.unimus.ac.id/index.php/perawat/article/view/254/254.

Wilson, B. J., Smith, S. L., Potter, W. J., Kunkel, D., Linz, D., Colvin, C. M., \& 
Donnerstein, E. (2002). Violence in children's television programming: Assessing the risks. Journal of Communication, 52(1), 5-35. doi: 10.1111/j.14602466.2002.tb02531.x.

Wilson, B. J. (2008). Media and children's aggression, fear, and altruism. Journal of the Future of Children, 18(1), 87-118. 